Historia Slavorum Occidentis

2021, nr 4 (31)

ISSN 2084-1213

DOI: $10.15804 /$ hso210410

Tomasz Nakoneczny (Poznań)

ORCID: 0000-0002-4241-7862

\title{
Wybrane problemy współczesnego dyskursu kresoznawczego w Polsce. Rekonesans
}

Keywords: Eastern Borderlands, borderland discourse, literary-centrism, postcolonial studies, geopolitical discourse

Słowa kluczowe: Kresy Wschodnie, dyskurs kresowy, literaturocentryzm, studia postkolonialne, dyskurs geopolityczny

Abstract: The article attempts to summarize the key, in the author's opinion, threads of the contemporary border-science debate. The point of reference are: Polish literary-centricism, which assigns the main role to literature in shaping the national world-view canon, and the interwar borderland debate, defined by the then geopolitical situation and orientalizing tendencies. Contemporary reflection on Borderlands Studies is mainly focused on developing a more realistic picture of the role of the Borderlands in Polish history.

\section{Założenia i cele artykułu}

Przedmiotem niniejszych rozważań będzie zmiana sposobu postrzegania Kresów Wschodnich przez część polskich elit humanistycznych, jaka nastąpiła w ciągu ostatniego trzydziestolecia. Główna i najważniejsza, zdaniem autora, linia ewolucyjna przebiegała tutaj - w ogólnych zarysach - od politycznej funkcjonalizacji Kresów w duchu polonocentrycznym i mocarstwowym (perspektywa dwudziestolecia międzywojennego, która stanowi tu kluczowy, choć nie zawsze uświadamiany układ odniesienia) do próby ich krytyczno-dekonstrukcyjnej redefinicji jako konstruktu kulturowego tudzież projektu politycznego maskującego istotne wady oraz słabości 
polskich systemów kulturowo-politycznej (auto)reprezentacji (perspektywa Trzeciej RP). Kontrapunktem przez cały ten czas, podobnie jak w wieku XIX, pozostawał szeroko rozumiany dyskurs literacko-artystyczny, odwołujący się do bazowego dlań imaginarium romantycznego, wyznaczający właściwe sobie układy orientacyjne, wchodzący przy tym nieustannie w różnego rodzaju fuzje ideowe z pozostałymi odmianami metakresowych narracji.

Momentem problematyzującym wywód będzie pytanie o rzeczywistą naturę (de)mitologizacji Kresów, z jaką mamy obecnie do czynienia, głównie w krytyczno-dekonstrukcyjnym nurcie polskiego dyskursu kresoznawczego. Czy można ją uznać za etap - być może ostateczny już - złożonego procesu depolonizacji/depolonocentryzacji Kresów, zapoczątkowanego w 1772 r. (pierwszy rozbiór) i przypieczętowanego postanowieniami jałtańskimi; etap równoznaczny w ostatecznym rozrachunku z unieważnieniem konstruktu kresowego jako nośnika treści ideologicznych oraz zepchnięciem go do wyłącznej roli residuum pamięci? Czy dekonstrukcja mitu połączona $\mathrm{z}$ deterytorializacją jego społeczno-przestrzennej podstawy oznacza w danym przypadku nieuchronność przyjęcia innej - w założeniu realnej - perspektywy oglądu? Kto, w jaki sposób i w oparciu o jakie kryteria aksjologiczne miałby tę nową, oczyszczoną poznawczo oraz moralnie perspektywę narracyjnie zagospodarowywać, ustalać obowiązujące w odniesieniu do niej normy ocenne, rozstrzygać pojawiające się kwestie sporne? To ostatnie nabiera szczególnej wagi w kontekście naturalnej wielokulturowości rozpatrywanego obszaru, wielopodmiotowości toczącej się wokół niego debaty.

By zmierzyć się z tymi pytaniami, zasadne byłoby porównawcze odwołanie się do wcześniejszych, zwłaszcza przedwojennych, form ideologizacji Kresów, będących pierwszą nowoczesną, przebiegającą $\mathrm{w}$ warunkach niepodległego bytu państwowego próbą konfrontacji mitu kresowego z wymogami Realpolitik, z żywą, skomplikowaną materią relacji międzykulturowych, międzyspołecznych oraz międzynarodowych. Tymczasem względy ekonomii wywodu, a także (choć w mniejszym stopniu) przyjęte przez autora założenia natury koncepcyjnej, skłaniają do znacznych zawężeń przedmiotowo-problemowych. Międzywojenny dyskurs kresoznawczy przywołany zostanie zatem bardzo skrótowo, w stopniu niezbędnym do uchwycenia jego zasadniczych wątków. Ponadto wyłączona z rozważań zostanie literatura fikcjonalna wraz z jej niektórymi gatunkowymi peryferiami (memuarystyka, reportaż etc.). Niewielkie odstępstwa od tej reguły posłużą głównie do zilustrowania bądź wzmocnienia niektórych spośród prezentowanych tez. W zamian uwaga autora zostanie skierowana na kształtowanie się wizerunku Kresów w ramach dyskursu kresoznawczego, 
obejmującego teksty nawiązujące do ich ideologicznej percepcji (w dyskursie naukowym, popularnonaukowym, publicystycznym, publicznym). Rzeczone dyskursy nie tworzą wprawdzie w danym przypadku zwartej całości, lecz poddają się całościowemu wyodrębnieniu oraz wewnętrznej systematyzacji jako pewien kompleks tematyczno-problemowy nawiązujący do tych źródeł polskiej historii oraz polskiej kultury, za sprawą których Kresy Wschodnie uzyskały zupełnie unikatowy status: rezerwuaru rdzennych narodowych wartości, a także probierza trafności polskich wyborów geostrategicznych, który to wątek dochodzi dziś bodaj najczęściej do głosu podczas debat wokół tzw. polityki piastowskiej i jagiellońskiej.

Wyłączony z rozważań zostanie również okres PRL-u, nie dlatego, iżby należało go uznać za nieistotny w kontekście rozpatrywanej tematyki. Przeciwnie, zwłaszcza po roku 1956 mamy do czynienia z istną erupcją wątków kresowych i kresoznawczych, szczególnie w beletrystycznej tudzież beletryzującej domenie piśmiennictwa krajowego (i częściowo, selektywnie, adaptowanego emigracyjnego), znaczoną nazwiskami T. Konwickiego, J. Iwaszkiewicza, S. Vincenza, J. Wittlina, A. Boleckiej, A. Kuśniewicza, J. Stryjkowskiego, W. Odojewskiego, J. Mackiewicza, C. Miłosza i wielu innych. Chodzi o to, że blokowanie dyskursu kresowego przez władze komunistyczne i związane z tym jego rozliczne transmutacje, przybierające niekiedy formy mowy głęboko ezopowej, uruchamia cały szereg zmiennych interpretacyjnych zmuszających do wyjścia poza krąg zadań zakreślony na potrzeby niniejszego tekstu. Marginalnie również zostanie potraktowana, funkcjonująca w specyficznym kontekście diaspory emigracyjnej, literatura przedmiotu powstająca poza granicami PRL, w ramach której na szczególniejszą uwagę zasługują idee wywodzące się ze środowiska paryskiej „Kultury”, w tym zwłaszcza doktryna/koncepcja ULB (Ukraina, Litwa, Białoruś) Giedroycia i Mieroszewskiego.

\section{Dyferencjacja dyskursu kresoznawczego}

Zasadniczym układem odniesienia dla dzisiejszego rozumienia Kresów pozostaje dyskurs międzywojenny, choć samo pojęcie zrodziło się na gruncie literackim (połowa XIX w.), natomiast jego politycznych korzeni wolno doszukiwać się w odległym chronologicznie koncepcie „ziem oderwanych” (avulsa), zagarniętych przez Turcję i Rosję w XVII w. Skutecznej asymilacji pojęcia po 1921 r. sprzyjało niewątpliwie rozmycie się konstruktu byłego Wielkiego Księstwa Litewskiego oraz Litwy, a także wzmożone poczucie zagrożenia ze Wschodu, które tym wyraźniejszą czyniło świadomość istnienia rubieży cywilizacyjno-politycznych polskiego pogranicza oraz 
potrzebę ich konsolidacji. Polonocentryzacja Kresów jawiła się wielu tyleż jako imperatyw historyczny, ile jako wyzwanie czasu. Na powyższe okoliczności zwraca uwagę Przemysław Żurawski vel Grajewski:

Wieloetniczne Kresy Wschodnie, by stać się Kresami polskimi we współczesnym rozumieniu tego słowa, musiały być kresami państwa polskiego i tylko polskiego, a nie pograniczem połączonych unią państw wieloetnicznej Rzeczypospolitej Obojga Narodów. Klasyczna forma pojęcia Kresów wykształciła się zatem dopiero w latach międzywojennych i w osiągniętym wówczas kształcie, z dodatkiem martyrologii lat 1939-1956, została przeniesiona do pamięci zbiorowej Polaków, w której przetrwała do dziś1 ${ }^{1}$.

Odwrotną stroną politycznie motywowanego obrazu Kresów w okresie międzywojennym jako ziem pogranicznych, restytuowanych (wskutek postanowień traktatu ryskiego - nie w pełni jednak, co podsycało wiele istniejących podziałów ideologiczno-politycznych bądź tworzyło nowe), przeznaczonych do coraz ściślejszej integracji z odrodzonym państwem polskim, była ich egzotyzacja. Wynikała ona częściowo z niewiedzy, swoistego społecznego „zapomnienia” dziejów przedrozbiorowych, zauważonego przez Romana Wapińskiego², częściowo zaś była efektem orientalizacji tego obszaru w ówczesnym dyskursie kresoznawczym, które to zjawisko analizuje na wybranych przykładach Hanna Gosk ${ }^{3}$.

Ogląd Kresów Wschodnich dawnej Rzeczypospolitej, do pewnego czasu względnie jednolity w warstwie figuratywno-symbolicznej (sposób aksjologicznego mapowania przestrzeni, stałe formy odniesień symbolicznych etc.), w niemałej mierze za sprawą swoich emotywnych uwarunkowań, a także zrośniętej z nimi romantyczno-arkadyjskiej tradycji narracyjnej, uległ w ostatnich dekadach istotnemu zróżnicowaniu, zwłaszcza na gruncie tego, co w artykule określone zostało mianem dyskursu kresoznawczego.

Wokół Kresów, rozumianych zarówno jako terytorium polityczne, jak i symboliczno-narracyjna ikonosfera, wytworzyła się po 1989 r., podobnie jak po powstaniu styczniowym oraz u źródeł dwudziestolecia, wielowątkowa debata, niekiedy niuansująca, niekiedy zaś rewidująca niektóre z wcześniejszych stanowisk. Doprowadziło

1 P. Żurawski vel Grajewski, Kresy - dzieje pewnego pojęcia, https://teologiapolityczna.pl/ prof-przemyslaw-zurawski-vel-grajewski-kresy-dzieje-pewnego-pojecia-1 [dostęp: 29 VI 2021].

2 R. Wapiński, Polska i małe ojczyzny Polaków, Wrocław-Warszawa-Kraków 1994, s. 224.

3 H. Gosk, Polski dyskurs kresowy w niefikcjonalnych zapisach międzywojennych. Próba lektury w perspektywie postcolonial studies, Teksty Drugie (2008), nr 6, s. 20-33. 
to - w ogólnym rozrachunku - do poszerzenia tudzież wzmocnienia krytyczno-dekonstrukcyjnej perspektywy ich oglądu (kształtującej się od dawna, co najmniej od krakowskiej szkoły historycznej, lecz w nader wąskim, niekiedy zgoła utajonym, nurcie narodowej [auto]refleksji). W efekcie zaś przywiodło do degradacji wielu mitotwórczych aspektów fundujących ów ogląd narracji, do zakwestionowania ich polonocentrycznej optyki, a co za tym idzie do ich podmiotowej pluralizacji (zaczęto nie tylko „dostrzegać” heterogeniczność kultury kresowej, ale też prawo do jej „wspólposiadania” przez inne niż polska wspólnoty etniczno-językowe); wreszcie - do przewartościowań w sferze językowo-pojęciowej, za sprawą których samo mapowanie wielowymiarowego, funkcjonującego na przecięciu wielu kultur wycinka przestrzeni społecznej jako Kresów Wschodnich Rzeczpospolitej musi wydawać się pod pewnymi względami kłopotliwe, pod innymi natomiast wprost nieuprawnione. Nie sposób zaprzeczyć, że najpierw do wypracowania, a później pogłębienia takiego stanowiska walnie przyczyniła się słynna już doktryna Jerzego Giedroycia i Juliusza Mieroszewskiego, zakładająca wyrzeczenie się wszelkich rewizjonizmów w stosunku do wschodnich sąsiadów powojennej Polski, a także aktywne włączanie ich w orbitę wpływów cywilizacyjnych i politycznych Zachodu. Zrazu, w warunkach emigracyjnych, doktryna ta stanowiła ważne ogniwo sporów toczonych wokół kwestii aktualnego statusu oraz przyszłości dawnych Kresów, natomiast po 1989 r. stała się wytyczną dla polskiej polityki wschodniej, honorowaną przez wszystkie liczące się środowiska polityczne w kraju, której spektakularnym wyrazem jest sformułowany z inicjatywy polsko-szwedzkiej program Partnerstwa Wschodniego (2008 r.).

Brak tu miejsca na prezentację pełnego spektrum stanowisk, jakie się w ramach dyskursu kresoznawczego w ostatnim trzydziestoleciu zarysowały (warto przy tym pamiętać o jego zagranicznym kontekście, obiektywnie znaczącym, choć nie zawsze z należytą uwagą włączanym do polskich dyskusji, zwłaszcza o pracach litewskich, ukraińskich i białoruskich intelektualistów i badaczy, takich jak np. M. Riabczuk, J. Hrycak, I. Babkou, V. Safronovas). Warto tu natomiast odwołać się do taksonomii, którą w odniesieniu do współczesnego kresoznawczego polilogu posłużył się Tomasz Zarycki, wyodrębniając w nim dwa główne paradygmaty: konserwatywny i liberalny. Badacz ten wprawdzie swój podział odniósł do dyskursów częściowo lub w całości nawiązujących do słownika postkolonialnego, jego walor porządkujący ma jednak szerszy zasięg; ponadto wypada już teraz zaznaczyć, że perspektywa postkolonialna okaże się również ważną orientacją niniejszych rozważań, choć trzeba od razu wspomnieć, że jej płynny w niejednym miejscu kontur metodologiczny, a także wyraźna obecność komponentów ideologicznych (wiążąca się niewątpliwie 
z jej marksistowsko-poststrukturalistycznym rodowodem), ograniczają zaufanie do wiarygodności pojawiających się na jej gruncie propozycji i ustaleń, zwłaszcza po stronie tych historyków (oraz innych przedstawicieli humanistyki), którzy dają w swoich badaniach pierwszeństwo pracy źródłoznawczej. Autor niniejszych rozważań świadom jest kłopotliwości (przechodzącej niekiedy w aporetyczność) zestawień bardziej tradycyjnych metod badawczych z dyskursami krytycznymi motywowanymi względami etycznymi bądź politycznymi (do jakich niewątpliwie należą postcolonial studies). Uważa jednak zarazem, że cenną wartością wnoszoną przez te drugie do ogólnie rozumianego dyskursu akademickiego pozostaje m.in. ich zdolność do poszerzania pola komunikowalności, specyficznej formy badawczej deliberatywności, co w przypadku dyskursu kresoznawczego w widoczny już teraz sposób owocuje wymianą poglądów między badaczami reprezentującymi różne „strony” kresowego doświadczenia, dotąd limitowaną przez rozmaicie rozumianą „polityczną poprawność” bądź przez nadmierne przywiązanie do „czysto warsztatowego” referowania własnych stanowisk.

Wracając do T. Zaryckiego, warto zauważyć, że w paradygmacie konserwatywnym pomieścić można zatem wypowiedzi sytuujące Rzeczpospolitą $\mathrm{w}$ roli ofiary kolonialnej przemocy, a jej ziemie wschodnie - przestrzeni rywalizacji z Rosją i ZSRR. W liberalnym zaś Polska okazuje się „podwykonawcą europejskiego kolonializmu”4. Oba stanowiska niosą sporo implikacji szczegółowych, takich jak np. egzotyzacja/ orientalizacja Kresów w ramach pierwszego z nich czy generalna niechęć do posługiwania się nazwą Kresy jako narzędziem symbolicznego zawłaszczenia wobec narodów dziś je reprezentujących (litewskiego, białoruskiego i ukraińskiego) w ramach drugiego. Wprawdzie to, co określiłem mianem krytyczno-dekonstrukcyjnej perspektywy, pozwala się utożsamiać bardziej z paradygmatem liberalnym, możliwe jest jednak połączenie obu paradygmatów wspólnym węzłem problemowym, co nie neguje wszelako zasadności klasyfikacji Zaryckiego.

Otóż sama chronologia skłania do tego, by w polonocentrycznej „opcji” kresoznawczej widzieć podstawowy układ odniesienia, jako że to właśnie na polonocentrycznym gruncie zagadnienie Kresów jako wyodrębnionej ikonosfery, o własnym, unikatowym statusie społecznym, geopolitycznym i kulturowym, wyrosło. Niezależnie od tego, co można sądzić na temat polskiego kolonializmu tout court, dyskursywny „casus Kresów” nie zaistniałby bez naznaczonej sprzecznościami roli

4 T. Zarycki, Polskie dyskursy o „Wschodzie” wewnętrznym i zewnętrznym - próba analizy krytycznej, [w:] Polska wschodnia i orientalizm, red. T. Zarycki, Warszawa 2013, s. 186-206, tu, s. 194. 
(unifikującej, konsolidującej, różnicującej, wykluczającej, orientalizującej etc.), jaką odegrały tu Pierwsza i Druga Rzeczpospolita. Każda sensowna konfrontacja z zasobami archiwum kresowego, z konstytuującymi je mitami, ideami, obrazami czy materialnymi residuami, każda próba jego rewizji, uzupełnienia bądź dekonstrukcji, powinna uwzględniać to, że zasila je w znacznym stopniu polski kanon dyskursywny. Równie istotna jest tutaj umiejętność odwoływania się do kanonów oraz punktów widzenia narodów ościennych, w tym także rosyjskiego, systematycznie ekspulsowanego z przestrzeni debaty metakresowej bądź swoiście na jej gruncie instrumentalizowanego. Sprowadzanie udziału Rosji w archiwum kresowym do wymiaru militarnego, administracyjnego czy geopolitycznego w gruncie rzeczy tylko pogłębia jej (post)kolonialną nieuchwytność, na którą zwracała uwagę Ewa Thompson m.in. w swoich Trubadurach imperium ${ }^{5}$. Natomiast generalne pomijanie bądź pomniejszanie udziału czynnika polskiego, jak dzieje się to np. w dyskursie ukraińskim (Riabczuk, Hrycak), gdzie zastępowany jest on na ogół czynnikiem austriackim (Galicja Zachodnia), wypada uznać za przejaw nadmiernej, by tak rzec, prezentyzacji dyskursu. Warto zauważyć, że taka strategia, mniej czy bardziej subtelnej „anihilacji” danego etnosu czy danej kultury z określonych przestrzeni doświadczenia społecznego (historycznego), pomniejszania ich udziału w tym doświadczeniu bądź zastępowania go udziałem grup innorodnych (np. niepolskich żywiołów w Galicji Zachodniej), należy do najbardziej znamiennych (wielokrotnie przy tym opisanych w literaturze postkolonialnej) przejawów postkolonialnego uwikłania. Sygnalizuje istnienie nieprzepracowanych trudności i barier w relacjach wzajemnych podmiotów wspólnego doświadczenia, o jakim mowa.

Proces kanonizacji Kresów jako z jednej strony wysuniętego najdalej na wschód szańca cywilizacji łacińskiej, z drugiej zaś - jako bastionu polskości avant la lettre walecznej, romantycznej i pobożnej - ukształtowały, jak się wydaje, dwie polskie konstanty kulturowe, wykazujące się frapującą na tle zasadniczo niesprzyjających okoliczności historycznych żywotnością: polonocentryczny etos misji cywilizacyjnej na Wschodzie oraz nostalgia utraty, będąca reakcją na katastrofę państwa polsko-litewskiego, w skali ogólnonarodowej, stymulowaną w znacznej mierze przez dyskurs literacki, w szczególności romantyczny (trudno przecenić kluczową w tej mierze rolę twórców silnie uobecnionych w świadomości społecznej, tzw. wieszczów narodowych, ponadto E. Orzeszkowej czy H. Sienkiewicza z jego Trylogia, ale

5 E. Thompson, Trubadurzy imperium. Literatura rosyjska i kolonializm, tłum. A. Sierszulska, Kraków 2000. 
też autorów pomniejszych, takich jak A. Malczewski, J.B. Zaleski, S. Goszczyński, J.I. Kraszewski, K. Ujejski czy W. Pol $)^{6}$.

Nie sposób zaprzeczyć, że na przestrzeni ostatnich ponad dwóch stuleci kulturotwórcza rola Kresów Wschodnich okazała się wydatna i wielopłaszczyznowa, o czym świadczą choćby nieprzebrane liczby tekstów artystycznych, pamiętnikarskich, publicystycznych, naukowych i popularyzatorskich, a także bogata ikonografia (J. Brandt, M. Gierymski, J. Matejko, J. Stanisławski, L. Wyczółkowski i in.). Kompetentny kresoznawca powinien umieć postrzegać tę rolę przez pryzmat jej funkcji mitotwórczych, odpowiedzialnych za selektywny mechanizm absorpcji doświadczenia społecznego. Jednak eksploracja tego rozległego kontinuum habitualnego, jakie wyznacza historia i ewolucja społeczno-kulturowa Kresów, dokonywana wyłącznie przy użyciu instrumentarium mitograficznego (głównie przez literaturoznawców oraz kulturoznawców), jak dzieje się najczęściej, nie powinna być uważana za modelową; co najwyżej za komponent znacznie pojemniejszej strategii badawczej. Wydaje się, że ukierunkowanie badań na obiektywizującą kategorię pogranicza zamiast na pojęcie Kresów, semantycznie i emocjonalnie nacechowane (za sprawą swojej polonocentryczności), jest perspektywą nieuchronną, a przy tym coraz wyraźniej postulowaną. Nie brak w polskim dyskursie głosów uzasadniających pozostanie przy mitologemie kresowym (B. Hadaczek ${ }^{7}$ ) jako oddającym niepowtarzalną specyfikę dziejów i miejsca. Wsparcia udziela im, nieco paradoksalnie, zakorzenienie terminu w micie politycznym o dziewiętnastowiecznym rodowodzie, na które zwraca uwagę Edward Kasperski. Micie konotującym aspiracje do restauracji granic przedrozbiorowych, „w opozycji do realiów polityczno-administracyjnych, etnicznych i kulturowych", a przy okazji odsłaniającym swój geopolityczno-Wallersteinowski horyzont, i odnawianym współcześnie, w zmodyfikowanej formie, w polskiej myśli geopolitycznej (J. Bartosiak ${ }^{9}$.

6 Oczywiście, tematyka kresowa w literaturze polskiej uobecnia się już wcześniej i można ją wiązać co najmniej z siedemnastowieczną twórczością Szymona Szymonowica oraz braci Zimorowiców, Szymona i Józefa Bartłomieja. Jednak nie sposób jej powiązać z paradygmatem myślenia o Kresach, jaki wytworzył się w okresie porozbiorowym.

7 B. Hadaczek, Historia literatury kresowej, Szczecin 2008.

8 E. Kasperski, Kresy, pogranicza i mity. O metodologii badań nad literatura kresowa, [w:] Literatura i różnorodność. Kresy i pogranicza. E. Czaplejewicz, Królestwo różnorodności, E. Kasperski, Teoria i literatura $w$ sytuacji ponowoczesności, Warszawa 1996, s. 91-178, tu, s. $106-120$.

9 J. Bartosiak, Rzeczpospolita między lądem a morzem. O wojnie i pokoju, Warszawa 2018. 
Nie wchodząc w niuanse toczonych sporów, wydaje się, że słuszniej jest patrzeć na fenomen Kresów w perspektywie godzącej do pewnego stopnia konkurencyjne terminy („pogranicza” i „Kresów”): sytuując go z jednej strony na rozleglejszej płaszczyźnie czasowej, obejmującej kategorie długiego trwania (longue durée), z drugiej natomiast - na pojemniejszej skali porównawczej, uwzględniającej występowanie analogicznych obszarów - peryferyjnych, ideologicznie wyróżnionych, zmityzowanych - w dziejach innych państw/regionów. Z tego punktu widzenia polskie Kresy Wschodnie muszą się wydać w historii narodów europejskich mniej kulturowo i społecznie osobliwe, jak również mniej, by tak rzec, tożsame ze swoim symbolicznym nacechowaniem obszaru wyróżnionego.

Tak właśnie postrzega Kresy Janusz T. Hryniewicz, posługujący się w odniesieniu do nich terminem „regionu ideologicznego”, będącego splotem „czynników przestrzennych, kulturowych, ideologicznych i politycznych" o pewnych cechach uniwersalności, zbliżających polskie Kresy pod względem roli i znaczenia np. do niemieckich Prus. Splotem oznaczającym nie tylko terytorium o unikatowym statusie w ramach danej wspólnoty narodowej, wyodrębnionym przez jego pograniczne (najczęściej) usytuowanie w stosunku do innych wspólnot, postrzeganych jako wrogie lub „przeciwstawiające się stusznym interesom” 10 owej wspólnoty, ale również pewną funkcjonalną strukturę ideologiczną (re)konstruowaną stosownie do aktualizowanych w danym okresie celów politycznych. W konkluzji swoich rozważań badacz podnosi anachroniczny oraz „dysonansowy charakter” regionów ideologicznych w kontekście współczesnej geopolityki europejskiej, dążącej jego zdaniem do wyeliminowania tradycyjnych przyczyn konfliktów militarnych, wśród których poczesne miejsce zajmuje nacjonalizm/patriotyzm podsycany właśnie na gruncie stosunku do sakralizowanych przez zbiorową wyobraźnię peryferii narodowych ${ }^{11}$.

Ten ostatni pogląd wpisuje się bezpośrednio w nurt współczesnych narracji dotyczących Kresów, który określiłem mianem krytyczno-dekonstrukcyjnego. Jakkolwiek stanowisko Hryniewicza wypada uznać in toto za próbę obiektywizującego ujęcia fenomenu kresowego, nawiązującego do szkoły Annales oraz polskiej szkoły

\footnotetext{
10 J.T. Hryniewicz, Regiony ideologiczne w Polsce i Niemczech. Zarys procesów długiego trwania, Studia Regionalne i Lokalne 33 (2008), nr 3, s. 5-20, tu: s. 8.

11 „Jakkolwiek nie można zabronić kultywowania pamięci o przodkach i dawnych małych ojczyznach, tworzenia stron internetowych czy pisania pamiętników, działalność taka powinna mieć charakter prywatny, ewentualnie pozarządowy. Z tego względu krytycznie należy ocenić finansowanie przez państwo struktur i wydarzeń utrwalających istnienie regionów ideologicznych w polityce państwowej i pamięci zbiorowej”; tamże, s. 19.
} 
historii społeczno-gospodarczej (W. Kula) - ujęcia wolnego do fiksacji na figuratywno-symbolistycznym stereotypie Kresów jako generatorze nostalgiczno-martyrologicznych historii (charakterystycznej również dla niektórych tekstualizacji akademickich) - ostatnie akapity jego rozważań ujawniają osobliwy dysonans. Osobliwy i zarazem znamienny dla wielu innych prób „właściwego” usytuowania Kresów w polskiej historii i w polskim systemie (samo)postrzegania. Polega on na tym, że uwalniając kresowe imago z fundujących je nieprawidłowości (aksjologicznych, poznawczych), implicytnie wciąż przypisuje się mu potencjalną skłonność do ponownego uzależniania się od błędnych matryc. Sugeruje to występowanie odwiecznego i niejako nieusuwalnego „skażenia”, jakiemu podlega polskie myślenie o Kresach. Skażenia wynikającego, domyślnie, z osadzenia go na niewłaściwym fundamencie ideowo-politycznym, a także moralnym. Kresy, rozwijając tę myśl, to błędny w istocie projekt, zrodzony ze złych intencji i podatny na robienie zeń niewłaściwego użytku. Pomijając związane z takim myśleniem ryzyko anachroniczności, polegającej m.in. na upraszczającej retrospektywnej (ale również, jak w tym przypadku, prospektywnej) moralizacji zjawisk i procesów pozwalających się opisywać w bardziej neutralnych kategoriach poznawczych (np. geopolitycznych), warto odnotować przy tej okazji swoistą aporetyczność współczesnych diagnoz „syndromu” kresowego. Rozpoznając bowiem w Kresach znamiona projektu ideologicznego (antemurale christianitatis, narodowa Arkadia, źródło państwowo-politycznej konsolidacji, antymoskiewski bufor etc.), albo poprzestaje się na jego krytycznej konstatacji, albo, idąc dalej, zakreśla się możliwe do zaakceptowania granice jego obowiązywalności (związane z „niebezpieczeństwem” aktualizacji). Obserwację tę można uogólnić, traktując jako przykład ukazujący generalną trudność z „odmitologizowaniem” Kresów, z odczarowaniem tego, co w ich obrazie traktowane jest jako fantazmatyczne; w istocie w próbach tego rodzaju mamy raczej do czynienia ze „wzmożeniem” dyskursywnego „sporu o Kresy”.

Podobnie widzi ów problem, na kanwie swoich odniesień do znanej książki Jana Sowy Fantomowe ciało króla, związany z polską nauką białoruski historyk Anton Saifullayeu:

Próba demitologizacji, nawet za pomocą bardziej krytycznych instrumentów metodologicznych, w żadnym razie nie ujawnia zdolności dekonstrukcyjnych proponowanego przez Sowę ujęcia. Uznanie kryterium ideologicznego jako podstawowego w kresowaniu służy bardziej autorowi do ujawnienia kolonialnej postawy Polski, którą Sowa starannie odkrywa w całości opracowania. Powiązane zostają teoria postkolonialna z próbą demitologizacji przez ujawnienie natury 
ideologicznej kresów, co jeszcze bardziej podsyca dyskurs (a nie jemu przeczy) i nie demontuje go, choć takiej intencji najprawdopodobniej Sowa nie zakładał ${ }^{12}$.

Przykładów analogicznych procedur obchodzenia się z Kresami możemy w dzisiejszej refleksji metakresowej znaleźć całkiem sporo, co zdaje się tylko potwierdzać trafność powyższej obserwacji A. Saifullayeu. I tak, literaturoznawca Mieczysław Dąbrowski, idąc za argumentacją francuskiego historyka Daniela Beauvois, autora poczytnego w Polsce dzieła pt. Trójkąt ukraiński 1793-1914. Szlachta, carat i lud na Podolu, Wolyniu i Kijowszczyźnie ${ }^{13}$, gotów jest w ogóle zrezygnować z używania terminu „Kresy”, jako mogącego razić wschodnich sąsiadów Polski, lecz jak natychmiast zaznacza: „Rezygnacja ze słowa nie oznacza wszak likwidacji problemu, który - tak czy inaczej nazwany - istnieje nadal. Rzecz raczej w tym, aby odwrócić kierunek dyskursu, stępić jego ostrze, by stał się neutralny poznawczo i niezideologizowany" ${ }^{14}$.

Sedno zaś wspomnianego problemu leży w tym, że „grzechem polskiej myśli dotyczącej kresów jest jej rewizjonistyczna tonacja, mniej czy bardziej zręcznie ukryta, ale stale obecna"15. Argumentacja rozwijana na rzecz dezawuacji wszelkiego rodzaju polskich roszczeń do Kresów znajduje od lat silne wsparcie częściowo w samym autorytecie D. Beauvois m.in. jako badacza „z zewnątrz”, a więc niejako bardziej uprawnionego do formułowania sprawiedliwych, neutralnych sądów w odniesieniu do zagmatwanych „polskich spraw”, częściowo zaś w jego imponująco obszernej analizie podnoszącej znaczenie czynnika klasowego (jak wiadomo, argumentum ex oeconomiae należy do najtrudniejszych do odparcia). Prawomocność tej linii rozumowania zasadza się na przeświadczeniu autora Trójkąta ukraińskiego, że o ile polskie doświadczenie kresowe sprzed zaborów było czymś realnym, uświęconym przez wojny i opór stawiany obcym cywilizacyjnie najeźdźcom, o tyle w XIX w., zwłaszcza po powstaniu styczniowym, sprowadziło się ono do obrony interesu gospodarczego szlachty kresowej.

Pogląd ten, trywializujący polską obecność na Kresach, mityczną reprezentację tych ostatnich w literaturze, sztukach pięknych oraz dyskursie publicznym, każe traktować jako niewspółmierną do ich faktycznego znaczenia. W podobnym duchu

\footnotetext{
12 A. Saifullayeu, Postkolonialne historiografie. Casus jednego średniowiecza, Warszawa 2020, s. 61-62.

13 D. Beauvois, Trójkąt ukraiński 1793-1914. Szlachta, carat i lud na Podolu, Wołyniu i Kijowszczyźnie, tłum. K. Rutkowski, Lublin 2005.

14 M. Dąbrowski, Kresy w perspektywie krytyki postkolonialnej, Porównania (2008), nr 5, s. 91-111, tu: s. 93.

15 Tamże, s. 94.
} 
wypowiada się Janusz Tazbir w tekście Rola Kresów Wschodnich w dziejach Rzeczypospolitej, gdzie w pewnym momencie stwierdza wprost, że obserwowany przezeń przyrost literatury i wiedzy o Kresach pozostaje „w pewnej dysproporcji do faktycznego znaczenia tych ziem w naszych dziejach politycznych i kulturze" ${ }^{16}$.

Tego rodzaju sposób myślenia idzie w sukurs dość licznym opiniom współczesnych polskich badaczy, historyków, zwłaszcza chyba jednak literaturoznawców, które olbrzymią wagę Kresów w polskiej świadomości narodowej wiążą ze specyficznym momentem ich kulturowej instauracji, dokonującej się w ramach dziewiętnastowiecznego dyskursu literackiego, a także na kanwie dyskusji i postaw kształtujących się pod jego wpływem. Ten właśnie moment miałby odpowiadać za spłaszczenie w percepcji zbiorowej pozafiguratywnych wymiarów kresowej rzeczywistości: gospodarczego, demograficznego czy politycznego.

Różnice, jakie występują w kontekście dążeń do lokalizacji czasowej tudzież tekstualnej rzeczonego momentu (najczęściej bodaj formułowane propozycje obszarów/ podmiotów sprawczych to: literatura romantyczna tout court, Wielka Emigracja, Mickiewiczowski Pan Tadeusz, Mohort Wincentego Pola, spory ideowo-polityczne po klęsce powstania styczniowego, piłsudczykowski federalizm wraz z uruchamianymi pod jego sztandarem praktykami dyskursywno-politycznymi etc.), mogą nasuwać obawę, że mamy tutaj do czynienia z tym rodzajem miary nieuporządkowania, który świadczy o nader silnej potrzebie z(re)definiowania danego zjawiska ex post, nadania mu określonego sensu/uzasadnienia (moralnego, społecznego) oraz ukierunkowania (dziejowego, historiozoficznego) w świetle późniejszych wydarzeń. Potrzebie tak silnej, że mimowiednie pomniejszającej, a niekiedy wręcz ignorującej, złożoność owego zjawiska.

W przeciwieństwie do wcale obfitej na przestrzeni ostatnich kilku dekad literatury wspomnieniowej, a także literatury historycznej w wersji pop, relatywnie rzadko, na przykład, współczesny dyskurs kresoznawczy (w szczególności w swojej postkolonialnej wersji) wykazuje zainteresowanie pozamitycznymi/pozaideologicznymi obszarami kresowej historii: tym, co dotyczy samych mieszkańców Kresów, dawnych i dzisiejszych, w każdym razie tych spośród nich, którzy nie uczestniczyli aktywnie w budowaniu etosu kresowego jako wizjonerzy, literaci, historycy, politycy czy duchowni, lecz wypełniali (i nadal wypełniają) ramę codziennego życia jako Polacy, ze wszystkimi wynikającymi z tego faktu konsekwencjami, konkretną treścią egzystencjalną, kulturalną, ekonomiczną. Piszący te słowa podczas swoich wizyt na

16 J. Tazbir, Rola Kresów Wschodnich w dziejach Rzeczypospolitej, Prace Filologiczne. Seria Literaturoznawcza, 50 (2008), nr 1, s. 31-46, tu: s. 46. 
tzw. Kresach Północno-Wschodnich (Wileńszczyzna, Kowieńszczyzna) nie odniósł nigdy wrażenia, by ich polscy mieszkańcy żyli w cieniu wielkiego mitu kresowego. Poszukiwanie genezy (i uwiarygodnienia) kresowej nostalgii w sugestywnych wątkach dziewiętnastowiecznego literaturocentryzmu ma, rzecz jasna, swoje uzasadnienie źródłowe, nie powinno być jednak traktowane jako wyłączna płaszczyzna, na której określana jest rola i miejsce Kresów w polskiej świadomości narodowej.

Jedno wszelako wydaje się dziś nie podlegać dyskusji: wyłonił się w polskim dyskursie kresoznawczym swoiście literaturocentryczny model genezy Kresów jako tekstu kultury o formacyjnym, a jednocześnie ikonicznym charakterze. Jacek Kolbuszewski zwraca uwagę na kluczową w tej mierze rolę dwóch poematów W. Pola - przywołanego Mohorta oraz Pieśni o ziemi naszej - nieco już dziś zapomnianych, a przez to mogących jawić się jako osobliwości w kontekście przypisywania im roli sui generis tekstów założycielskich. Askrypcja do modelu literaturocentrycznego może być traktowana jako efekt braku alternatyw dyskursywnych, co z kolei podnosi interesująco Robert Traba: „Siła ukształtowanego wówczas kodu tożsamościowego polegała na tym, że wysokich lotów literatura oraz inicjacyjna siła narodzin mitu (wydarzenia z przełomu XVIII i XIX w.) spotkały się z brakiem równie silnej alternatywnej narracji i brakiem oczekiwań elit społecznych" ${ }^{17}$.

Przemawiałoby to za zasadnością eksploracji innego wątku w obszarze egzegezy kresologicznej niż lansowany dotąd dość szeroko wątek kompensacyjny (waloryzacja poetycka jako kompensacja utraty). Chodziłoby mianowicie o przyjrzenie się aktowi kreacji oraz dalszej ewolucji mitu kresowego pod kątem idiosynkratyczności oraz kontyngentności stojących za nim sił sprawczych. Wyodrębniona w tym celu perspektywa podmiotowa (obejmująca zarówno pojedynczych aktorów życia intelektualnego, jak i określone struktury środowiskowe czy klasowe), mogłaby zostać potraktowana - gdyby pójść dalej niż sugestia Traby - jako obszar wrażliwości i symbolicznej ekspresji, który wykształcił się w ramach endemicznych, wysoce przy tym specyficznych, uwarunkowań i którego faktyczna rola jako kulturowego ekwiwalentu sfery pozatekstualnej nie została wciąż rzetelnie rozpoznana (z dużym prawdopodobieństwem można przyjąć, że została ona nawet w niemałym stopniu przeszacowana).

Jak się ma zagadnienie przygodności - w sensie eksplanacyjnym - do utrwalonego w polskiej literaturze kresoznawczej binarnego modelu mapowania rzeczywi-

17 R. Traba, Kresy: miejsce pamięci w procesie reprodukcji kulturowej, [w:] Polska wschodnia i orientalizm, red. T. Zarycki, Warszawa 2013, s. 146-170, tu: s. 150. 
stości kresowej? Modelu totalizującego lub przynajmniej wyostrzającego charakterystyczne dla metakresowych form reprezentacji kontrasty i opozycje (swój-obcy, katolik-innowierca, utrata-idealizacja, nieobecność-fantonimizacja etc.)? Wydaje się, że detektory współczesnej kresologii winny być skierowane zarówno na sferę estetyczno-retorycznej immanencji syndromu literaturocentrycznego, z której wszak wyrasta nowoczesna (dziewiętnasto-i dwudziestowieczna) mitologia kresowa, jak również na jej specyficzny socjokulturowy korelat, czyli aktywną ideologicznie część elit, którą można w znacznej mierze utożsamiać z postszlachecką inteligencją, z jej unikatowymi aspiracjami, interesami i uprzedzeniami, odwołującą się do medium literackiego nierzadko przygodnie: już to jako po oręż ideologiczny, już to jako po narzędzie osobistej ekspresji etc.

Próba eksplikacji binaryzmu kresowego powinna się przeto zmierzyć z całym szeregiem zagadnień natury „technicznej”: proporcji oddziaływań, wag czynników, związków przyczynowo-skutkowych etc. Na przykład z pytaniem, w jakiej mierze wynika ów binaryzm ze strukturalnych właściwości życia kresowego, ze sposobu jego osadzenia w czasie, przestrzeni, demografii, w instytucjach politycznych, w historycznej procesualności wreszcie, w jakim zaś pozwala się opisywać w terminach zasugerowanej przed chwilą kulturowej kontyngencji. Nie dość jednak, że wszelkie przesądzenia mogą odbywać się tutaj ex post, na mocno już palimpsestowym gruncie ideologiczno-imagologicznym, to możliwość rekontekstualizacji Kresów w duchu innym niż postkolonialny jawi się dziś jako zasadniczo utopijna. Przesądził o tym, jak się zdaje, polonocentryczny moment sprawczy wraz z jego cechami dystynktywnymi. Powołanie do życia „polskich Kresów” jako tekstu kultury utkanego z polskich konstant i idiosynkrazji w okresie budzenia się świadomości narodów sąsiedzkich nie mogło nie ukierunkować całego dyskursu kresowego na tory rywalizacji, przemocy i budowania/utrwalania statusowej nierównorzędności. Wszelkie skierowane w przeszłość (Pierwsza Rzeczpospolita) interpolacje pozytywnie rozumianej wielokulturowości, synergii rozwojowej, musiały odtąd - o ile nie chciały pozostać czystymi manifestami politycznymi - liczyć się z kontestacją ze strony podmiotów zewnętrznych, nieakceptujących na ogół polskiego sposobu symboliczno-narracyjnej kanonizacji Kresów. Radykalnym wariantem takiego podejścia jest stanowisko J. Sowy uważającego polską obecność na Kresach za na wskroś obcą i narzuconą, a polskie - szeroko rozumiane - „prawa” do Kresów za fantazmatyczne.

Mocno zawężona u zarania perspektywa podmiotowa dyskursu kresowego - ze względu na dominację pierwiastka polonocentrycznego (klasowego) - sprawia, że wszelkie jego (re)animacje naznaczone są od początku szczególnego rodzaju drama- 
tyzmem: klasowy ekskluzywizm miesza się tu z narodową idiosynkratycznością, patos przeszłości z polityką podejrzeń, projekty wielokulturowości z nacjonalizmami. Jeśli wszelako opcja polonocentryczna może być uważana za wyłącznie historyczne odniesienie, a platforma wielokulturowości w praktyce za nacechowany resentymentem i stronniczością wielogłos, to $\mathrm{z}$ dużą zasadnością rozbrzmiewa pytanie zadane przez T. Zaryckiego w jego recenzji książki J. Sowy: „jakie prawo mają do udziału $\mathrm{w}$ tym procesie tworzenia wiedzy poszczególne grupy narodowe i kto powinien je reprezentować?”. I jak dalej zauważa badacz: „stawką w grze wydaje się tu samo prawo do mówienia o kresach, prawo do udziału w wytwarzaniu ich dominującego obrazu w dyskursach globalnych" ${ }^{18}$. Wszystko to razem sprawia, że status szczególnego forum dyskusyjnego zyskuje $\mathrm{w}$ danym przypadku debata postkolonialna.

\section{Przymus postkolonialności?}

Immanentną cechą postkolonialnych rozpoznań polskiego kazusu pozostaje uznanie moralnej ambiwalencji Rzeczypospolitej jako z jednej strony ofiary imperialnej przemocy (w relacji z zaborcami, głównie rosyjskim, później zaś - z hegemonem sowieckim), z drugiej natomiast jako kolonizatora (w stosunku do niepolskich „narodów kresowych”, zwłaszcza Litwinów, Białorusinów i Ukraińców). Oba człony ambiwalencji jawią się, w świetle toczących się wciąż wokół nich sporów i polemik, jako dyskusyjne. W obu wypadkach wyróżnieniu ulega rola Kresów jako przestrzeni ekspansji i peryferyzacji, znajdujących odzwierciedlenie w przeciwstawianych sobie, lecz dopełniających się w istocie dyskursach hegemonicznym i wiktymistycznym. Przy czym osią wspomnianych sporów jest nie sam fakt występowania owych dyskursów, lecz pytanie, czy stojące za nimi praktyki i zależności odpowiadają kryteriom dominacji i podporządkowania ustalanym przez teorię postkolonialną. Podnoszona w tym kontekście po wielekroć przez badaczy-postkolonialistów kwestia ram czasowych kolonializmu, a także jego mechanizmów sprawczych oraz społeczno-kulturowych implikacji, odsłania, mimo etycznej i problemowej spójności teorii, frapującą chwiejność interpretacyjną w odniesieniu do wielu poszczególnych kazusów historycznych (nie inaczej jest z Kresami).

Ta chwiejność stąd się chyba bierze - zauważa Aleksander Fiut - że krytyka postkolonialna jest nierzadko, choć nie zawsze, pośrednią formą reaktywacji -

18 T. Zarycki, Jan Sowa, Fantomowe ciało króla. Peryferyjne zmagania z nowoczesna formą, Stan Rzeczy, 3 (2012), nr 2, 222-230, tu: s. 226-227. 
jakże europejskiego! - mitu o powrocie do nieskażonej pierwotności, do raju kultury autentycznej, źródłowej, pozbawionej obcych, zniekształcających ją elementów. Prezentyzm idzie tu nierzadko w parze z anachronizmem, a zatem rzutowaniem w przeszłość nowożytnego rozumienia narodu i świadomości narodowej. Stąd wyprawy w czasie mają najwyraźniej charakter mitotwórczy i ideologiczny. Wreszcie - zaciera się rozróżnienie pomiędzy teorią podboju, który stał u kolebki większości państw europejskich, a kolonizacją ${ }^{19}$.

Wypowiedź ta, podejmująca ważkie zagadnienie metodologiczne postcolonial studies, odnosi się w szczególny sposób do Kresów rozumianych jako postkolonialny temat. Uzmysławia to zwłaszcza zestawienie współczesnych prac historiograficznych poświęconych (re)kultywacji pamięci o Kresach, ukierunkowanych na danie świadectwa ich historyczno-kulturowego bogactwa, przede wszystkim rzecz jasna na podkreślenie w nim polskiego udziału (R. Aftanazy ${ }^{20}, M$. Bogucka ${ }^{21}, Z$ Z. Hauser ${ }^{22}$, S. Koper ${ }^{23}$, W. Mędrzecki ${ }^{24}$, S.S. Nicieja ${ }^{25}$ i in.), z generalnie krytyczną w stosunku do konceptu „polskości Kresów”, niekiedy nawet radykalnie, szkołą postkolonialną. Obie strategie, jakkolwiek w upotocznionym już dziś odczytaniu postrzegane jako wykluczające się (mitologizacja versus demitologizacja), wydają się dążyć - na pewnym poziomie uogólnienia - do jednakiego celu: oczyszczenia obrazu Kresów z wszelkich, zaciemniających jego źródłową postać, naleciałości. W jakiej mierze powoduje nimi zauważony przez A. Fiuta prezentyzm, w jakiej zaś dążenie „do nieskażonej pierwotności”, pozostaje zagadnieniem do szerszej dyskusji. Prof. Stanisław Sławomir Nicieja, który podjął się przeglądu ważniejszych polskojęzycznych prac historycznych na temat Kresów, jakie powstały w minionym trzydziestoleciu, prze-

19 A. Fiut, Polonizacja? Kolonizacja?, Teksty Drugie (2003), nr 6, s. 150-156, tu: s. 155.

20 R. Aftanazy, Dzieje rezydencji na dawnych Kresach Rzeczypospolitej, t. 1-11, Wrocław 1991-1997.

21 M. Bogucka, Ludzie z Kresów, Warszawa 2010.

22 Z. Hauser, Podróże po cmentarzach Ukrainy - dawnej Małopolski Wschodniej, t. 1-4, Warszawa-Kraków 1998-2009.

23 S. Koper, Ukraina. Przewodnik historyczny. Polskie ślady, tragiczne dzieje, Warszawa 2011; tenże, Wielkie Księstwo Litewskie i Inflanty. Przewodnik historyczny śladami polskości Kresów, Warszawa 2014; tenże, Kresy Potudniowo-Wschodnie, Warszawa 2015 i in.

24 W. Mędrzecki, Kresowy kalejdoskop. Wędrówki przez Ziemie Wschodnie Drugiej Rzeczypospolitej 1918-1939, Kraków 2018.

25 S.S. Nicieja, Kresowa Atlantyda. Historia i mitologia miast kresowych, t. 1-13, Opole 2012-2019. 
ciwstawia je stanowiskom postkolonialnym (zwłaszcza D. Beauvois), które dyskredytuje jako wyolbrzymione, stronnicze, a w ostatecznym rozrachunku - prezentystyczne właśnie. Mitologizowanie Kresów, które sam zresztą umieszcza na rozległym tle historycznym, widzi jako zjawisko złożone, częściowo odpowiadające faktom, częściowo zaś koloryzujące je bądź wypaczające ${ }^{26}$.

Jakkolwiek wywód prof. Niciei przenika troska o zrównoważony i sprawiedliwy ogląd problematyki kresowej (zwłaszcza w odniesieniu do jej warstwy ocennej), zdaje się on pośrednio upoważniać do fundamentalnego pytania o wiarygodność dyskursu kresoznawczego, zarówno in toto, jak i poszczególnych jego nurtów, w szczególności zaś postkolonialnego. W obszarze tego ostatniego za najbardziej reprezentatywne mogą dziś uchodzić głosy Bogusława Bakuły i Dariusza Skórczewskiego. Pierwszy z badaczy źródła kresowej „aberracji” („kresomanii”) Polaków polegającej na nadmiernym, historycznie nieuzasadnionym, przywiązaniu do mityzacyjnych aspektów dyskursu kresowego, upatruje w zapośredniczeniu oglądu rzeczywistości polskich peryferii wschodnich przez fikcję literacką, która uniemożliwiła „racjonalną ocenę historyczną, zwłaszcza w czasach rozbiorów, a potem komunistycznego izolacjonizmu; fikcja ta budowała mitologię utraconej ojczyzny, cierpienia, ofiary" ${ }^{27}$. Stwierdzenie to jest prawdziwe w tej przynajmniej mierze, że - jak zostało zauważone wcześniej - imaginarium literackie pozostaje stałym kontrapunktem polskich przedstawień kresoznawczych, trudno też przecenić przełomową w budowaniu mitologii kresowej rolę nostalgii utraty, zasilanej symbolicznie i aksjologicznie przez polski literaturocentryzm oraz przez pochodzący z dawniejszych czasów misjonizm cywilizacyjny. Słusznie też zwraca uwagę Bakuła na zasadnicze niedowartościowanie (często manifestujące się jawnym wykluczeniem) w polskich reprezentacjach kresoznawczych elementu innorodnego, ruskiego, ukraińskiego czy litewskiego, co odpowiada schematom orientalizacyjnym znanym z relacji międzykulturowych/międzyetnicznych opisywanych przez szkołę Saidowską.

Badacz idzie jednak dalej, dostrzegając w polskich projekcjach Kresów oznaki swego rodzaju esencjalizmu narodowego.

Każdy, kto wydaje tęskny - pisze on - głos w sprawie „kresów”, jest prawdziwym Polakiem. Inni to właśnie wyłącznie Inni. Zabieranie głosu w sprawie

\footnotetext{
26 Tenże, Historia i mitologia Kresów Wschodnich Rzeczypospolitej, Wschodni Rocznik Humanistyczny 17 (2020), nr 3, s. 265-286.

27 B. Bakuła, Kolonialne i postkolonialne aspekty polskiego dyskursu kresoznawczego (zarys problematyki), Teksty Drugie 6 (2006), s. 11-33, tu: s. 13.
} 
„kresów” sytuuje mówiącego w centrum narodowego dyskursu polskiego, potwierdzając narodową tożsamość niemal na zasadzie magicznego zaklęcia. Jest to jednak taka definicja tożsamości, która wyklucza Innych ${ }^{28}$.

Wypada jednak zastanowić się, czy „kresomania”, którą Bakuła z takim przekonaniem dezawuuje, nie jest - przynajmniej w odniesieniu do ostatniego trzydziestolecia - reakcją na zamrożenie dyskursu kresoznawczego w okresie PRL-u daleko bardziej niż reaktywowaną mityzacją spod znaku dawnego literaturocentryzmu, nacjonalizmu czy kolonializmu.

Podobnym tropem podąża D. Skórczewski w artykule Melancholia dyskursu kresoznawczego, choć jest on bardziej powściągliwy w formułowaniu uogólnień: nie stawia znaku równości między polską tożsamością a stosunkiem do Kresów. Przedmiotem jego uwagi pozostaje „historycznie i geograficznie, a nawet geopolitycznie, uwarunkowany” "podmiot dyskursu kresoznawczego” ${ }^{29}$, który stoi, podobnie jak w niniejszych artykule, za niekrytyczną lub nie dość krytyczną (czytaj: nie-postkolonialną) lekcją hermeneutyki kresoznawczej. Stawką integralności tak rozumianego podmiotu, a także jego zdolności do odnalezienia się w realiach współczesnego świata, jest przezwyciężenie traumy utraty, którą badacz rozpatruje w kategoriach freudowskiej psychoanalizy:

Ponawiając - za pomocą inscenizowanej kulturowo melancholii - „gest utraty", stara się [podmiot dyskursu kresoznawczego - przyp. T.N.] ocalić swą tożsamość i integralność, narażone na szwank w wyniku rosyjskiej i sowieckiej hegemonii. Wysiłki te nieuchronnie przybierają postać szczególnego rodzaju narcyzmu, który uznać można za uboczny produkt podporządkowania, natomiast w melancholii, jaka z tego narcyzmu wypływa, odsłania się instrument kulturowej „samoobrony”. Melancholia ta jest bowiem próbą przezwyciężenia wspomnianej „wyrwy” w tożsamości, np. za pomocą estetyzacji i mitologizacji „Kresów”. Z tej perspektywy dyskurs kresoznawczy można postrzegać jako deformujące lustro, w którym przegląda się postkolonialny podmiot, nie zdając sobie do końca sprawy ze swej postkolonialnej kondycji ${ }^{30}$.

Skórczewski trafia, jak się wydaje, w sedno, przywołując wątek hegemonii rosyjskiej/sowieckiej w funkcji siły sprawczej mechanizmów odpowiedzialnych za

28 Tamże, s. 15.

29 D. Skórczewski, Melancholia dyskursu kresoznawczego, Porównania 11 (2012), nr 2, s. 25-138 , tu: s. 133.

30 Tamże. 
specyficzne formy przeżywania doświadczenia kresowego. Zarówno „treść” tego doświadczenia (czynnik rosyjski jako źródło stosunków dominacji), jak jego „forma” (melancholia jako korelat deficytu tożsamościowego) zdają się przesądzać o nieuchronności jego (post)kolonialnej kontekstualizacji, ponieważ dopiero ona pozwala wpisać dyskurs kresoznawczy w ramę istotnych związków przyczynowo-skutkowych. Polscy postkolonialiści nie idą jednak na ogół za geopolitycznym tropem przywołanym mimochodem przez Skórczewskiego. Tropem, który mógłby doprowadzić do podważenia monopolu estetyzującej kresologii zakorzenionej w paradygmacie literaturoznawczym, a który otwarcie podejmują autorzy o orientacji prawicowej, o której za chwilę.

Okazuje się jednocześnie, że nawet zawężając pragmatycznie kontekst postkolonialny do „wyselekcjonowanej” podstawy w postaci dyskursu kresoznawczego, nie sposób uniknąć jego powiązania ze znacznie większą skalą odniesienia, jaką wyznacza polska tożsamość narodowa. W innym swoim tekście Skórczewski pisze już explicite o dawnych Kresach jako o „utraconej części polskiej genealogii narodowej, tym samym zaś również polskiej podmiotowości”31 , zadając przy tym pytanie o to, czy:

dyskurs kresoznawczy skazany jest na zawieszenie między dwiema skrajnościami: studiami postkolonialnymi w wersji, która nie rozpoznaje postkolonialnej melancholii, jaką się ów dyskurs żywi, a tradycyjnie pojmowanymi badaniami historycznoliterackimi, dla których melancholia ta stanowi ukrytą i nieuświadomioną siłę napędową $?^{32}$.

Pytanie jest znamienne, podobnie jak odpowiedź, której udziela autor, postulujący przyjęcie postawy rozumiejącej wobec mechanizmów funkcjonowania melancholii, zamiast szukania dla niej usprawiedliwień czy jej potępiania. Znamienność polega na tym, że dyskurs (postkolonialny), który wypada uznać za forpocztę prawdziwie krytycznego, demitologizującego nurtu refleksji kresoznawczej, okazuje się pozostawać w ramie modalnej, której sam się formalnie przeciwstawia. Terapia proponowana przez Skórczewskiego, podobnie jak imperatyw depolonocentryzacji Bakuły, utrzymują dyskurs w kręgu myślenia etyczno-emotywnego. Obaj badacze identyfikują nieprawidłowości (już to psychologicznej, już to etycznej natury),

31 Tenże, Paraliż tożsamości, czyli dyskurs kresoznawczy w potrzasku postkolonialnej melancholii, [w:] Polska wschodnia i orientalizm, red. T. Zarycki, Warszawa 2013, s. 171-185, tu: s. 181.

32 Tamże. 
proponują ich naprawę, lecz nie unieważnia to przecież faktu, że Kresy jako tekst kultury były i pozostają komponentem polskiego systemu samopostrzegania, a jako taki - regionem ideologicznym; a także tego, że historyczna depolonizacja Kresów po 1945 r., postkolonialna ich depolonocentryzacja po 1989 r., nie znoszą kwestii poruszonej przez Zaryckiego: prawa do symboliczno-narracyjnego reprezentowania tego obszaru wobec wspólnot zewnętrznych (ościennych, ponadregionalnych, globalnych etc.), do kształtowania jego aksjologicznego obrazu. Jak słusznie zauważa Stanisław Uliasz, „dyskurs kresoznawczy znajduje się w sytuacji szczególnej, gdyż problem «Kresów» współokreśla «jądro polskości»; nie można zeń uczynić jedynie «kresomanii»"33.

Inną, obok wymienionej, „słabością” postkolonialnej kresologii jest jej binaryzm w odniesieniu do struktury zależności kolonialnych na Kresach, narzucający z właściwą sobie apodyktycznością dwie możliwe opcje: bycia podmiotem albo przedmiotem kolonizacji. Krystyna Romaniszyn, która w artykule Dyskurs postkolonialny a dzieje Polski podjęła się zestawienia argumentów pro et contra polskiej kolonialności (rozumianej właśnie binarnie: podmiotowo oraz przedmiotowo), słusznie zwraca uwagę na to, że problemy interpretacyjne z Kresami „wynikają po części z faktu, że lwią część tych dziejów tworzyła po wszystkich stronach inna warstwa społeczna niż ta, z której wywodzą się jej współcześni interpretatorzy”34. Ale przecież nie da się również zaprzeczyć, że i konfiguracje zależności dominacji i podporządkowania (w tym również centro-peryferyjnych) są tutaj wielopoziomowe i wieloaspektowe, a exemplum modelowym pozostaje w tej mierze Galicja, o której Danuta Sosnowska w tekście Ograniczenia i możliwości krytyki postkolonialnej pisze, że przedstawia „skomplikowany i rozgałęziony system kulturowej rywalizacji, a często przemocy, w którym niemal każdy bywał ofiarą i opresorem. Dodatkowo problem komplikuje fakt, że nie było tu jednego centrum i jednej peryferii ${ }^{35}$ ".

Na pytanie postawione w niniejszym fragmencie artykułu wypada zatem odpowiedzieć niejednoznacznie: podążanie debaty postkolonialnej tropem literaturocentrycznym (przynajmniej w znacznej mierze) powoduje w pewnym sensie utrwalanie się binarnego obrazu Kresów, a także uproszczonego sposobu ich dyskursywnego

\footnotetext{
33 S. Uliasz, Problem Kresów w literaturze polskiej lat 1918-2018. Znaczące perspektywy interpretacyjne, Tematy i Konteksty 13 (2018), nr 8, s. 17-42, tu: s. 37.

34 K. Romaniszyn, Dyskurs postkolonialny a dzieje Polski, Studia Polonijne 34 (2013), s. 7-38, tu: s. 37.

35 D. Sosnowska, Ograniczenia i możliwości krytyki postkolonialnej, Historyka 42 (2012), s. 89-99, tu: s. 95 .
} 
redefiniowania. Ten mechanizm, raz uruchomiony, wykazuje tendencję do zwielokrotniania trudności związanych z samookreślaniem się podmiotów debaty w obliczu dychotomii Swój-Obcy, dominujący-podporządkowany. Możliwość wyjścia z tego swoiście „przymusowego” położenia należałoby chyba wiązać ze znacznym poszerzeniem kompetencji dyskursywnych i przedmiotowych (co koresponduje z koncepcją komparatystyki integralnej B. Bakuły) ${ }^{36}$.

\section{Inne próby ideologicznego „urealnienia” obrazu Kresów}

Dyskurs postkolonialny rozprawia się głównie z literaturocentrycznym dziedzictwem Kresów, marginalizując - z takich czy innych powodów - jego wymiary pozasymboliczne, w szczególności geopolityczny. Ten ostatni stał się przedmiotem ożywionej debaty we współczesnym dyskursie prawicowym, uprawianym głównie w obszarze publicystyki historycznej. Nawiązuje on szeroko do spuścizny rodzimej myśli geopolitycznej międzywojnia (A.M. Bocheński, S. Cat-Mackiewicz, W. Studnicki i in.). Zagadnienie obecności Kresów w polskiej spuściźnie historycznej jest tutaj rozpatrywane, jak lubią podkreślać przedstawiciele tego nurtu (P. Zychowicz, R. Ziemkiewicz, S. Cenckiewicz, B. Radziejewski, J. Bartosiak, L. Sykulski i in.), w kategoriach polityki realnej, przeciwstawianej romantyczno-utopijnym wizjom orientacji, która w niniejszym artykule skojarzona została z postawą mitograficzną/literaturocentryczną. Kluczowy z geopolitycznego punktu widzenia łańcuch zdarzeń, rozpoczęty próbą odzyskania Kresów podjętą u schyłku pierwszej wojny światowej, a zakończony ich pojałtańskią amputacją (z traktatem ryskim, polityką wschodnią Drugiej RP oraz gehenną drugiej wojny światowej pomiędzy tymi biegunami), jest tutaj rozpatrywany w kategoriach pragmatyki siły oraz skuteczności działania. Zarówno utrata kresów określanych jako zewnętrzne (traktat ryski), jak i tzw. województw wschodnich Drugiej RP (porozumienia jałtańskie), są postrzegane w tym kontekście najczęściej jako rezultat porażki na niwie wielowiekowej rywalizacji z moskiewsko-petersburskim ośrodkiem siły w jego różnych politycznych wcieleniach. „Polska - zauważa J. Bartosiak - została w ten sposób po II wojnie światowej ograniczona do swojego obszaru rdzeniowego bez żadnych buforów na wschodzie oraz z oddanym jej terenem poniemieckim na zachodzie i północy, który czynił ją zależną od Związku Sowieckiego jako gwaranta bezpieczeństwa wasalnego

36 B. Bakuła, W stronę komparatystyki integralnej, Porównania 1 (2004), s. 7-16. 
PRL-u ${ }^{37 ”}$. Istotnym tego następstwem są znaczące przemieszczenia w regionalnym układzie sił, a w ostatecznej konsekwencji - osłabienie potencjału Polski jako podmiotu na geopolitycznym agonie. Rzutuje to w poważnym stopniu na ocenę kondycji geopolitycznej dzisiejszej Polski.

Ograniczona do potencjału demograficznego - pisze Piotr Zychowicz tylko jednego z tworzących ją niegdyś narodów stała się ona cieniem dawnej Rzeczypospolitej. Tak jest do dziś. Czymże jest bowiem te niecałe 40 milionów Polaków, gdy z jednej strony ma się Niemcy, a z drugiej Rosję? Polska po traktacie ryskim przestała być podmiotem, a stała się przedmiotem dziejów. Polakom pozostały zaś tylko sny o minionej chwale ${ }^{38}$.

Jakkolwiek akceptowane są powszechnie w rozpatrywanym środowisku antyrewizjonistyczne implikacje doktryny Giedroycia-Mieroszewskiego, postulowana jest tutaj znaczna aktywizacja polskiej polityki wschodniej zmierzająca do (od)budowy, przynajmniej częściowej, polskich wpływów na wschodnich rubieżach RP, motywowana już to potrzebą uzyskania odpowiedniego dystansu wobec Federacji Rosyjskiej, już to przekonaniem o potencjalnej istotności i historycznie uwarunkowanej trwałości związków z dawnymi Kresami oraz państwami je „reprezentującymi” (koncept pomostu bałtycko-czarnomorskiego), co z kolei wypada uznać za nawiązanie, nie zawsze wszak jednoznaczne, do koncepcji federacyjnej J. Piłsudskiego.

Nie brak jednak w tym obszarze refleksji prób sui generis racjonalizacji utraty Kresów, przez podkreślenie dodatnich stron polskich granic powojennych, a także potrzeby odcięcia się od kresowych sentymentów na rzecz trzeźwej polityki w stosunku do wschodnich sąsiadów współczesnej Polski (E. Thompson). Odznacza się na tym tle zwłaszcza wypowiedź publicysty prawicowego Piotra Semki, domagającego się „dowartościowania” polskich kresów zachodnich (tzw. Ziemie Odzyskane) kosztem energii wkładanej w kultywację pamięci o kresach wschodnich, w której autor ten widzi zagrożenie związane z możliwością przeoczenia procesów germanizacyjnych dokonujących się na pierwszym z obszarów ${ }^{39}$.

Stanowiska prawicowo-geopolityczne splatają się w wielu istotnych punktach z perspektywą wallersteinowsko-braudelowską, do której nawiązałem w kontekście konceptu regionu ideologicznego. Wiedzie ono, podobnie jak w tamtym wypadku,

37 J. Bartosiak, Rzeczpospolita między lądem..., s. 261.

38 P. Zychowicz, Pakt Pitsudski-Lenin, czyli jak Polacy uratowali bolszewizm i zmarnowali szansę na budowę imperium, Poznań 2015, s. 424.

39 P. Semka, Więcej szacunku dla Kresów Zachodnich, Do Rzeczy, 26 IV 2015, nr 17. 
do wtapiania polskiego pogranicza (tak jak każdego innego) w szerszy horyzont procesów dziejowych, w ramach których klasyczne binaryzmy kulturowe w rodzaju Wschód-Zachód, ufundowane w znacznej mierze na rozróżnieniach symbolicznych, ulegają pewnej relatywizacji, stając się metonimicznym wyrazem dynamicznych i sekularnych sił społeczno-gospodarczych.

Na porównywalnej skali - toutes proportions gardées - operuje współczesny dyskurs mityzacyjny, nawiązujący w tej mierze do konceptu Europy Środkowej Milana Kundery, a także - na co zwraca uwagę Ewa Wiegandt - do „Niesamowitej Słowiańszczyzny” Marii Janion ${ }^{40}$. Polska „kresowość” wtapiałaby się w takim ujęciu w nieporównanie bardziej uniwersalną kategorię Europy Środkowej, „kulturowe pogranicze rozpościerające się między sowieckim Wschodem i euroatlantyckim Zachodem, pomysł na konstruowanie europejskiej tożsamości i formacji kulturowej przekraczającej opozycję Wschód-Zachód”41. Tendencję tę można dostrzec nader wyraźnie w prozie oraz eseistyce Andrzeja Stasiuka, w której przyjmuje ona specyficzną (podobnie jak u ukraińskiego „odpowiednika” Stasiuka - Jurija Andruchowycza), oniryczno-filozoficzną postać:

Jeśli miałbym wymyślić dla Europy Środkowej jakiś herb, to w jednym z jego pól umieściłbym półmrok, a w jakimś innym pustkę. To pierwsze jako znak nieoczywistości, to drugie jako znak wciąż nieoswojonej przestrzeni. Bardzo piękny herb o nieco niewyraźnych konturach, które można wypełnić wyobraźnią. Albo snem $^{42}$.

\section{Wnioski końcowe}

Ewolucja myślenia o Kresach, o której była mowa na początku niniejszych rozważań, przebiegała pod znakiem prób urealnienia - różnie rozumianego - ich miejsca i roli w polskiej historii tudzież w sferze polskiego systemu samopostrzegania (tożsamościowego). Dyskurs postkolonialny, który podjął się głównie rewizji rodzimych form autoprezentacji w kontekście relacji z Innym/Obcym, ich moralnych bądź emotywnych uwarunkowań, nie udzielił jak dotąd zadowalających odpowiedzi na pytania

\footnotetext{
40 E. Wiegandt, Kresy we wspótczesnych badaniach literackich, Prace Filologiczne. Seria Literaturoznawcza 50 (2008), nr 1, s. 77-90, tu: s. 84.

41 Tamże.

42 J. Andruchowycz, A. Stasiuk, Moja Europa. Dwa eseje o Europie zwanej Środkowa, Wołowiec 2007, s. 114.
} 
dotyczące prawomocności/celowości swoich propozycji/rozstrzygnięć w obliczu wielopodmiotowego kulturowo i narodowo skonfigurowania dyskursu kresoznawczego. Dyskurs natomiast prawicowo-geopolityczny nie może się wciąż wykazać należytą skutecznością we (współ)kształtowaniu tego, co sam określa mianem polityki wschodniej Trzeciej RP, jego przeto uroszczenia i postulaty wypada traktować jako w znacznej mierze niezweryfikowane ekstrapolacje. Żywym elementem debaty postkolonialnej pozostaje nadal czynnik mityzacyjny, uobecniający się najżywiej, tradycyjnie już, w dyskursie literackim, ukierunkowany coraz bardziej zauważalnie na przezwyciężanie binarności charakteryzującej wcześniejsze formacje mityzacyjne.

Wszystko to sprawia, że nie sposób dziś mówić o zwieńczeniu dyskursu kresoznawczego jakąś formułą dezaktualizującą jego kulturotwórczy potencjał i zamykającą go nieodwołalnie w domenie historii. Wydaje się, że jego dalszą możliwą ewolucję określą dwa wyznaczniki, częściowo zbieżne: potrzeba ustalenia konsensualnych reguł (w szerszym, międzynarodowym wymiarze) debaty kresoznawczej oraz procesy zachodzące w szeroko pojętej sferze geopolitycznej, z wyróżnioną w niej rolą takich konstruktów jak Unia Europejska oraz doktryna/polityka Międzymorza, wymuszające lub oddalające możliwość redefinicji regionalnych powiązań zakorzenionych w głęboko i zarazem szeroko rozumianej perspektywie historycznej.

\section{Bibliografia}

Aftanazy R., Dzieje rezydencji na dawnych Kresach Rzeczypospolitej, t. 1-11, Wrocław 1991-1997.

Andruchowycz J., Stasiuk A., Moja Europa. Dwa eseje o Europie zwanej Środkowa, Wołowiec 2007.

Bakuła B., Kolonialne i postkolonialne aspekty polskiego dyskursu kresoznawczego (zarys problematyki), Teksty Drugie 6 (2006), s. 11-33.

Bakuła B., W stronę komparatystyki integralnej, Porównania 1 (2004), s. 7-16.

Bartosiak J., Rzeczpospolita między lądem a morzem. O wojnie i pokoju, Warszawa 2018. Beauvois D., Trójkąt ukraiński 1793-1914. Szlachta, carat i lud na Podolu, Wolyniu i Kijowszczyźnie, tłum. K. Rutkowski, Lublin 2005.

Bogucka M., Ludzie z Kresów, Warszawa 2010.

Dąbrowski M., Kresy w perspektywie krytyki postkolonialnej, Porównania 5 (2008), s. 91-111.

Fiut A., Polonizacja? Kolonizacja?, Teksty Drugie 6 (2003), s. 150-156. 
Gosk H., Polski dyskurs kresowy w niefikcjonalnych zapisach międzywojennych. Próba lektury w perspektywie postcolonial studies, Teksty Drugie 6 (2008), s. 20-33.

Hadaczek B., Historia literatury kresowej, Szczecin 2008.

Hauser Z., Podróże po cmentarzach Ukrainy - dawnej Małopolski Wschodniej, t. 1-4, Warszawa-Kraków 1998-2009.

Hryniewicz J.T., Regiony ideologiczne w Polsce i Niemczech. Zarys procesów dtugiego trwania, Studia Regionalne i Lokalne 33 (2008), nr 3, s. 5-20.

Kasperski E., Kresy, pogranicza i mity. O metodologii badań nad literatura kresowa, [w: ] Literatura i różnorodność. Kresy i pogranicza. E. Czaplejewicz, Królestwo różnorodności, E. Kasperski, Teoria i literatura w sytuacji ponowoczesności, Warszawa 1996, s. 91-178.

Koper S., Kresy Południowo-Wschodnie, Warszawa 2015.

Koper S., Ukraina. Przewodnik historyczny. Polskie ślady, tragiczne dzieje, Warszawa 2011.

Koper S., Wielkie Księstwo Litewskie i Inflanty. Przewodnik historyczny śladami polskości Kresów, Warszawa 2014.

Mędrzecki W., Kresowy kalejdoskop. Wędrówki przez Ziemie Wschodnie Drugiej Rzeczypospolitej 1918-1939, Kraków 2018.

Nicieja S.S., Historia i mitologia Kresów Wschodnich Rzeczypospolitej, Wschodni Rocznik Humanistyczny 17 (2020), nr 3, s. 265-286.

Nicieja S. S., Kresowa Atlantyda. Historia i mitologia miast kresowych, t. 1-13, Opole 2012-2019.

Romaniszyn K., Dyskurs postkolonialny a dzieje Polski, Studia Polonijne 34 (2013), s. 7-38.

Saifullayeu A., Postkolonialne historiografie. Casus jednego średniowiecza, Warszawa 2020.

Semka P., Więcej szacunku dla Kresów Zachodnich, Do Rzeczy, 26 IV 2015, nr 17.

Skórczewski D., Melancholia dyskursu kresoznawczego, Porównania 11 (2012), nr 2, s. $125-138$.

Skórczewski D., Paraliż tożsamości, czyli dyskurs kresoznawczy w potrzasku postkolonialnej melancholii, [w: Polska wschodnia i orientalizm, red. T. Zarycki, Warszawa 2013, s. 171-185.

Sosnowska D., Ograniczenia i możliwości krytyki postkolonialnej, Historyka 42 (2012), s. 89-99.

Tazbir J., Rola Kresów Wschodnich w dziejach Rzeczypospolitej, Prace Filologiczne. Seria Literaturoznawcza 50 (2008), nr 1, s. 31-46. 
Thompson E., Trubadurzy imperium. Literatura rosyjska i kolonializm, thum. A. Sierszulska, Kraków 2000.

Traba R., Kresy: miejsce pamięci w procesie reprodukcji kulturowej, [w:] Polska wschodnia i orientalizm, red. T. Zarycki, Warszawa 2013, s. 146-170.

Uliasz S., Problem Kresów w literaturze polskiej lat 1918-2018. Znaczace perspektywy interpretacyjne, Tematy i Konteksty 13 (2018), nr 8, s. 17-42.

Wapiński R., Polska i małe ojczyzny Polaków, Wrocław-Warszawa-Kraków 1994.

Wiegandt W., Kresy we wspótczesnych badaniach literackich, Prace Filologiczne. Seria Literaturoznawcza 50 (2008), nr 1, s. 77-90.

Zarycki T., Jan Sowa. Fantomowe ciato króla. Peryferyjne zmagania z nowoczesna forma, Stan Rzeczy 3 (2012), nr 2, s. 222-230.

Zarycki T., Polskie dyskursy o „Wschodzie” wewnętrznym i zewnętrznym - próba analizy krytycznej, [w:] Polska wschodnia i orientalizm, red. T. Zarycki, Warszawa 2013, s. 186-206.

Zychowicz P., Pakt Pitsudski-Lenin, czyli jak Polacy uratowali bolszewizm i zmarnowali szansę na budowę imperium, Poznań 2015.

Żurawski vel Grajewski P., Kresy - dzieje pewnego pojęcia, https://teologiapolityczna. $\mathrm{pl}$ /prof-przemyslaw-zurawski-vel-grajewski-kresy-dzieje-pewnego-pojecia-1.

\section{Summary}

Selected problems of contemporary borderland discourse in Poland. Reconnaissance

The Eastern Borderlands of the former Republic of Poland, both as a text of culture and as a socio-political reality, played a role that cannot be overestimated in shaping the Polish national identity. The basic canon of ideas, as well as the paradigm of experiencing ties with the Borderlands, were shaped within the framework of the Polish literary-centric tradition. On this basis, a strongly idealized image of the Polish Borderlands was created. Contemporary Polish postcolonial discourse, treated in the article as a critical and deconstructive part of the borderland discourse, is confronted with this image. However, it does not resolve fundamental issues concerning legitimacy in the borderland science debate. The nature of the contemporary border studies debate shows that the loss of the Borderland by Poland in 1945 resolved the issue of the nationality of this area, but did not invalidate the ideological character of this region. 
Nadesłany: 12 III 2021

Nadesłany po poprawkach: 17 IX 2021

Zaakceptowany: 30 IX 2021

Dr Tomasz Nakoneczny

Uniwersytet im. Adama Mickiewicza w Poznaniu

Wydział Historii

ul. Uniwersytetu Poznańskiego 7

61-614 Poznań

e-mail: tomnak@amu.edu.pl 